\title{
MENINGKATKAN KETERAMPILAN BELAJAR MAHASISWA DENGAN MODUL BELAJAR MANDIRI
}

\author{
Suprayekti, Hirmana Wargahadibrata, \& Cecep Kustandi \\ e-mail: suprayekti.tp.unj@gmail.com \\ Teknologi Pendidikan Universitas Negeri Jakarta
}

\author{
Jalan Rawamangun Muka Jakarta Timur
}

\begin{abstract}
Abstrak: Keterampilan belajar berfungsi sebagai pondasi utama agar mahasiswa mampu berprestasi dalam studi dan mampu mengaktualisasikan dirinya secara optimal dalam dunia kerja. Namun, kenyataannya mayoritas mahasiswa belum memiliki keterampilan belajar yang mencakup kemampuan: mengingat efektif, membuat jadwal belajar, mencatat efektif, membaca cepat dan efektif, dan merumuskan tujuan kuliah secara spesifik. Penelitian ini bertujuan untuk menghasilkan sumber belajar mandiri (modul) untuk memfasilitasi belajar mahasiswa dalam mengembangkan keterampilan belajar di perguruan tinggi/ universitas. Metode penelitian yang digunakan adalah penelitian pengembangan dengan menggunakan model pengembangan Rowntree. Penelitian ini dilaksanakan selama 11 bulan, mulai bulan Januari hingga November 2014 di FIP UNJ. Hasil penelitian menunjukkan bahwa, baik pada tahap expert review, one to one evaluation, small group, maupun field trials, Modul Keterampilan Belajar untuk Mahasiswa sudah baik. Modul Keterampilan Belajar untuk Mahasiswa telah terbukti dapat meningkatkan keterampilan belajar mahasiswa. Implikasi penelitian ini adalah dengan adanya modul keterampilan belajar memfasilitasi mahasiswa untuk belajar mandiri dan mengembangkan keterampilan belajar sehingga mampu mencapai kompetensi lulusan yang diharapkan
\end{abstract}

Kata-kata Kunci: sumber belajar, modul, belajar mandiri, keterampilan belajar.

\section{IMPROVING STUDENTS' LEARNING SKILLS TROUGH SELF-LEARNING MODUL}

\begin{abstract}
Learning skill functions as the basic foundation to enable the students to attain good learning achievement and practice optimal self-actualization at their work places. However, in fact majority of the students have not possessed learning skills for effective remembering, planning learning schedule, effective note-taking, fast and effective reading. This research aims at producing self-study module to facilitate the students to improve their learning skill in higher education. The model applied in this research was Rowntree's research and development. The research was conducted for 11 months as from Jan through November 2014 in The School, Education of State University of Jakarta.The research result showed the module was effective based on expert review, one to one evaluation, small group, and field trials. It could improve the students' learning skill. The implication of this study is the module facilitates the students to learn independently and develop their learning skills so that they can achieve the expected graduate competence.
\end{abstract}

Keywords: learning resource, module, learning independently, learning skill.

\section{PENDAHULUAN}

Di era globalisasi, perkembangan teknologi dirasakan begitu cepat. Perkembangan tersebut menuntut perkembangan sumber daya manusia (SDM) yang berkualitas. Menurut data dari Human Development Indeks tahun 2011, kualitas SDM Indonesia berada di posisi 108, masih jauh di bawah Malaysia (peringkat 57), Thailand (peringkat
92), bahkan Filipina (peringkat 97). Hal tersebut didukung dengan masih banyaknya pngangguran di Indonesia. Hingga pada Agustus 2013, tercatat jumlah pengangguran di Indonesia mencapai 7,39 juta jiwa atau $6,25 \%$ yang secara umum mengalami peningkatan persentase Tingkat Pengangguran Terbuka (TPT) sebesar 0,33\% dibandingkan TPT pada bulan Februari 2013.

Pengangguran merupakan masalah bangsa 
yang tidak pernah selesai. Ada tiga hambatan yang menjadi alasan kenapa orang tidak bekerja, yaitu hambatan kultural, kurikulum sekolah, dan pasar kerja. Hambatan kultural yang dimaksud adalah menyangkut budaya dan etos kerja. Sementara yang menjadi masalah dari kurikulum sekolah adalah belum adanya standar baku kurikulum pengajaran di sekolah yang mampu menciptakan dan mengembangkan kemandirian SDM yang sesuai dengan kebutuhan dunia kerja. Sedangkan hambatan pasar kerja lebih disebabkan oleh rendahnya kualitas SDM yang ada untuk memenuhi kebutuhan pasar kerja.

Universitas Negeri Jakarta (UNJ) mengemban fungsi untuk mengembangkan potensi SDM di bidang pendidikan dan nonkependidikan yang mandiri dan memiliki integritas sesuai dengan tuntutan pembangunan yang berkesinambungan. Kompetensi lulusan UNJ antara lain harus memiliki kemampuan professional yang tinggi, kewirausahaan yang profesional, kemampuan mengembangkan IPTEK, dan kemampuan untuk meningkatkan kualitas diri, wawasan, dan sikap dalam melaksanakan tugas keprofesionalannya. Untuk mencapai kompetensi lulusan UNJ tersebut, dibutuhkan penguasaan keterampilan belajar. Mahasiswa UNJ harus memiliki keterampilan belajar agar mampu berprestasi dan mampu mengaktualisasikan dirinya secara optimal dalam dunia kerja. Budiarjo (2008) menjelaskan bahwa dengan peserta didik memiliki keterampilan belajar, berarti dapat mempercepat untuk belajar, sehingga belajar akan memberi makna pada setiap apa yang sedang peserta didik pelajari. Oleh karena itu, keterampilan belajar memiliki peranan yang penting untuk mencapai proses aktualisasi diri individu di lingkungan masyarakat, sekaligus peserta didik mampu mengembangkan segala potensi pada dirinya serta dapat memberi makna di setiap apa yang dipelajari peserta didik.

Berdasarkan studi pendahuluan yang dilakukan terhadap 120 mahasiswa di Fakultas Ilmu Pendidikan, Universitas Negeri Jakarta pada tahun 2013 menunjukkan bahwa sebagian besar mahasiswa $(82,22 \%)$ mengaku sudah mengetahui gaya belajarnya. Gaya belajar kinerstetik (48,5\%) mendominasi mahasiswa FIP UNJ dibandingkan dengan gaya belajar visual $(29,2 \%)$ dan auditori (22, $3 \%)$. Mereka juga mempertimbangkan lingkungan dalam mempersiapkan belajar. Sedangkan untuk kemampuan mahasiswa dalam mengingat efektif $26,67 \%$; membuat jadwal belajar $30 \%$; mencatat efektif $32,58 \%$; membaca efektif $47,13 \%$; dan membuat presentasi $52,81 \%$. Hal tersebut menunjukkan bahwa kemampuan sebagian besar mahasiswa masih rendah dalam mengingat efektif, membuat jadwal belajar, mencatat efektif, dan membaca efektif.

Hasil studi pendahuluan juga menunjukkan bahwa sebagian besar (70\%) mahasiswa memiliki kemampuan belajar mandiri. Hal tersebut didukung oleh motivasi kuat yang dimiliki $(87,21 \%)$. Selain itu, pada dasarnya sebagian besar mahasiswa telah mengetahui tujuan (goals) dari kuliah, namun tujuan tersebut masih secara umum dan belum spesifik/ operasional. Dengan demikian dibutuhkan bahan belajar mandiri untuk meningkatkan keterampilan belajar yang dimiliki oleh mahasiswa.

Berdasarkan penjelasan yang telah diuraikan di atas, maka rumusan masalah dalam penelitian ini adalah "Bahan belajar mandiri seperti apa yang mampu meningkatkan keterampilan belajar mahasiswa?". Penelitian ini bertujuan untuk menghasilkan bahan belajar mandiri yang dapat membantu mahasiswa meningkatkan keterampilan belajar yang dimilikinya.

Sitepu (2008) menyebutkan bahwa dalam proses belajar dan membelajarkan, secara rinci sumber belajar dapat berfungsi untuk meningkatkan kualitas proses dan hasil belajar dengan karena sumber belajar dapat mempercepat laju belajar dan membantu pendidik menggunakan waktu secara lebih efisien. Sumber belajar juga berfungsi membina dan mengembangkan gairah peserta didik sehingga dapat mengurangi beban guru dalam menyajikan informasi. Dengan adanya sumber belajar maka memberikan kemungkinan belajar bersifat lebih individual dengan jalan mengurangi kontrol guru yang kaku dan tradisional serta memberikan kesempatan kepada peserta didik untuk belajar sesuai dengan kemampuannya. Selain itu, sumber belajar memberikan dasar yang lebih ilmiah dengan jalan merencanakan program pembelajaran yang lebih sistematis serta mengembangkan bahan pembelajaran yang dilandasi penelitian. Sumber belajar menjadikan pembelajaran lebih mantap dengan jalan meningkatkan kemampuan manusia dalam menggunakan berbagai media komunikasi serta penyajian data dan informasi secara lebih konkret.

Dalam penelitian ini, sumber belajar yang digunakan adalah bahan belajar mandiri berupa modul yang berfungsi mengurangi beban dosen dalam menyajikan informasi sehingga dapat lebih 
banyak membina dan mengembangkan gairah mahasiswa serta dapat memberikan kemungkinan belajar bersifat lebih individual dengan jalan mengurangi kontrol dosen yang kaku dan tradisional serta memberikan kesempatan kepada mahasiswa untuk belajar sesuai dengan kemampuannya. Sedangkan bahan belajar mandiri mempunyai manfaat untuk memberikan informasi yang akurat serta memberikan motivasi positif sehingga mampu merangsang mahasiswa untuk berpikir dan bersikap lebih lanjut.

Modul pada hakikatnya merupakan media yang dapat disusun dan dipergunakan untuk keperluan pembelajaran konvensional dan mandiri. Pemilihan modul cetak sebagai media pembelajaran dianggap perlu karena efektif dan efisien sebagai suatu sistem yang lengkap, berisi rangkaian kegiatan pembelajaran yang dirancang secara sistematis serta berisi tujuan belajar yang dirumuskan secara jelas dan khusus. Dengan adanya modul keterampilan belajar, diharapkan dapat membantu mahasiswa UNJ dalam mengembangkan keterampilan belajarnya secara mandiri. Fungsi modul adalah bahan ajar yang dinamis karena dapat digunakan untuk belajar mandiri atau pembelajaran konvensional (bersama fasilitator). Modul dapat digunakan dalam setiap proses pembelajaran mulai dari memberi motivasi, memberi informasi, sampai dengan menilai hasil belajar.

Modul mempunyai beberapa kelebihan dibandingkan dengan buku teks pelajaran. Modul mempunyai struktur lebih rinci, komponen sistem pembelajaran yang lengkap, dan disusun berdasarkan kaidah disain pesan. Dalam penelitian ini, modul memiliki tiga bagian utama yaitu pendahuluan, penyajian, dan bagian penutup. Dalam pengembangan modul keterampilan belajar, peneliti akan memperhatikan dan menggunakan komponenkomponen modul secara utuh, diantaranya bagian pendahuluan (deskripsi singkat, relevansi, dan tujuan pembelajaran), bagian penyajian (judul kegiatan belajar, uraian, contoh atau noncontoh, latihan dan rangkuman), serta bagian penutup (tes formatif, umpan balik, dan tindak lanjut).

Selain itu, untuk memperkuat alasan pemilihan modul sebagai bahan ajar yang tepat untuk mengembangkan keterampilan belajar, dilakukan analisis terhadap bahan ajar keterampilan belajar, yang telah dikembangkan sebelumnya sebagai berikut.

Pertama, modul keterampilan belajar yang merupakan bagian dari Pelatihan Keterampilan Belajar yang dikembangkan oleh Irma Fitriani pada tahun 2011. Pemanfaatan bahan ajar keterampilan belajar digunakan saat pelatihan di kelas dengan bimbingan dari trainer. Materi yang dikembangkan cukup luas namun kurang mendalam mencakup 10 kompetensi dengan tujuan pembelajaran ranah kognitif C1, C2 dan C3.

Kedua, pengembangan buku ajar di luar negeri dari berbagai sumber dari universitas di Amerika dan Eropa, juga mengharuskan fasilitator sebagai pendamping untuk memanfaatkan buku ajar tersebut.

Ketiga, bahan ajar yang ada berupa handout pelatihan biasanya dalam bentuk powerpoint, trainer memberikan pelatihan dengan menggunakan presentasi tersebut. Bahan ajar yang dikembangkan biasanya hanya per topik misalkan membaca cepat, mengelola waktu, dan lain sebagainya. Materi yang dikembangkan juga tidak komprehensif karena dibuat per bagian terpisah dan deskripsi materi hanya berupa pointers-pointers. Buku bacaan yang ada di pasaran masih bersifat umum, tidak memiliki tujuan pembelajaran yang spesifik dan terukur. Selain itu isi materi tidak disesuaikan dengan kebutuhan mahasiswa di perguruan tinggi.

Menurut Rowntree, ada tiga langkah yang ditempuh untuk menghasilkan sebuah modul atau bahan ajar konvensional (buku). Pertama, tahap perencanaan, meliputi menentukan rofil pemelajar, menentukan tujuan pembelajaran, membuat garis besar (outline) isi pembelajaran, memilih media penyampaian, merencanakan pendukung pembelajaran, dan mempertimbangkan bahan ajar yang ada. Kedua, tahap persiapan penulisan meliputi: batasan dan sumber daya, mengurutkan gagasan, menentukan kegiatan belajar dan umpan balik, tentukan contoh, menentukan gambar atau grafis yang sesuai, menentukan perangkat akses, serta menentukan format bahan ajar. Ketiga, penulisan dan penyuntingan meliputi: memulai draf pertama, melengkapi dan mengedit draf pertama, menuliskan bahan penilaian, serta uji coba dan perbaikan.

Menurut Budiarjo (2008), belajar bagaimana belajar berarti peserta didik mampu mengontrol belajar mereka dan menentukan bagaimana berinteraksi dengan lingkungan. Kemampuan demikian menyebabkan proses berpikir seseorang unik serta memampukan peserta didik berpikir kritis dan kreatif. Ia pun berkompetensi dalam memecahkan masalah, mengambil keputusan, dan mengevaluasi kasus. 
Beberapa keterampilan yang harus dimiliki peserta didik, antara lain: (1) belajar bagaimana menemukan gaya belajar, (2) belajar bagaimana belajar menulis, (3) belajar bagaimana belajar menghafal, dan (4) belajar bagaimana belajar dengan sistem kredit semester (SKS). Mempelajari cara belajar adalah pengetahuan tentang cara belajar itu sendiri.

Menurut Fry (2008), aspek-aspek mempelajari cara belajar, antara lain: (1) mempelajari belajar dengan benar, (2) menemukan gaya belajar, (3) mengelola belajar, (4) Membaca dan mengingat, (5) Mengatur waktu, (6) Menjadi unggul di kelas, (7) Melakukan penelitian, (8) Menyusun karya tulis yang bermutu, (9) Belajar untuk menghadapi ujian.

DePorter \& Hernacki (2001) menjelaskan bahwa aspek-aspek yang mendukung keterampilan belajar, yaitu: (1) Kekuatan AMBAK (Apa Manfaatnya BagiKu?), (2) Lingkungan belajar yang tepat, (3) Memupuk sikap juara, (4) Gaya belajar, (5) Gaya berpikir, (6) Teknik mencatat, (7) Teknik menulis, (8) Meningkatkan daya ingat, (9) Kekuatan membaca, dan (10) Berpikir kreatif.

Berdasarkan pernyataan di atas dapat disimpulkan bahwa keterampilan belajar adalah proses pengoptimalan belajar dengan didukung oleh aspek-aspek belajar, seperti persiapan belajar (conditioning learning) gaya belajar, gaya berpikir, keterampilan membaca, teknik mencatat, dan keterampilan meningkatkan daya ingat serta membuat jadwal belajar (harian, mingguan dan bulanan) sehingga peserta didik dapat mengembangkan potensi yang ada pada dirinya. Setiap tokoh menyebut keterampilan belajar dengan kata yang berbeda, seperti belajar bagaimana belajar, learning how to learn, dan mempelajari cara belajar. Namun semua kata tersebut memiliki satu makna yang sama, yakni keterampilan belajar.

\section{METODE PENELITIAN}

Metode penelitian yang digunakan adalah penelitian pengembangan dengan menggunakan model pengembangan Rowntree. Penelitian ini dilaksanakan pada bulan Januari 2014 hingga November 2014 di FIP UNJ

Teknik pengumpulan data yang digunakan adalah melalui studi dokumentasi, wawancara, dan penyebaran angket. Studi dokumentasi dilakukan sebagai bahan untuk penyusunan materi modul. Wawancara penyebaran angket dilakukan kepada tiga orang ahli (ahli modul dan desain pembelajaran, ahli materi, dan ahli bahasa), serta lima orang mahasiswa pada tahap one to one evaluation. Penyebaran angket juga dilakukan kepada 10 orang mahasiswa pada tahap small group dan 20 orang mahasiswa pada tahap field trial. Analisis dalam penelitian ini menggunakan teknik deskriptif kualitatif.

\section{HASIL DAN PEMBAHASAN}

\section{Hasil Pengembangan}

Modul Keterampilan Belajar untuk Mahasiswa telah melewati ujicoba yang meliputi: (a) expert review, (b) one to one evaluation, (c) small group, dan (d) field trials yang hasilnya dijelaskan sebagai berikut.

\section{a. Expert Review}

Pada penelitian ini melibatkan tiga orang ahli, yaitu (a) ahli desain dan media pembelajaran, (b) ahli materi, serta (c) ahli bahasa. Ahli desain dan media pembelajaran yang dimaksud adalah Prof. Dr. Bintang Petrus Sitepu, MA. merupakan guru besar Universitas Negeri Jakarta. Beliau berprofesi sebagai dosen di jurusan Kurikulum dan Teknologi Pendidikan FIP UNJ. Untuk ahli materi, yaitu Bapak Yovan P Putra. Beliau merupakan praktisi dalam bidang keterampilan belajar, yaitu sebagai peak-performance learning coach sekaligus pemilik dari perusahaan Total Mind Learning. Untuk ahli Bahasa, yaitu Ibu Retno Widyaningrum, lulusan S1 Ilmu Komunikasi dan S2 Manajemen Universitas Indonesia, merupakan dosen jurusan Kurikulum dan Teknologi Pendidikan FIP UNJ. Selain itu, beliau juga berperan sebagai editor di Jurnal Ilmiah VISI PTK PAUDNI dan Jurnal PERSPEKTIF Ilmu Pendidikan, Universitas Negeri Jakarta. Hasil ujicoba ketiga ahli tersebut dijelaskan sebagai berikut.

1. Ahli Materi Keterampilan Belajar

Dari hasil penyebaran kuesioner dan wawancara, ahli materi keterampilan belajar menyatakan bahwa modul yang dikembangkan sudah baik. Terdapat beberapa masukan dari ahli materi keterampilan belajar.

Berdasarkan masukan yang diberikan, ahli materi keterampilan belajar mengatakan bahwa secara umum modul keterampilan belajar untuk mahasiswa dapat memberikan penjelasan kepada mahasiswa mengenai keterampilan belajar, walaupun masih terdapat beberapa item yang juga sangat penting untuk dibahas, misalnya terkiat dengan konsentrasi. Modul tersebut mempunyai beberapa kelebihan, antara lain menggunakan gaya bahasa 
yang sederhana dan informal, pembahasan yang tidak terlalu panjang sehingga mempermudah kebanyakan mahasiswa untuk mempelajarinya, serta adanya latihan evaluasi untuk menguji pemahaman mahasiswa.

Namun demikian, modul keterampilan belajar untuk mahasiswa juga mempunyai beberapa kekurangan, antara lain tidak tersedianya subbab troubleshooting, yang berisi berbagai alternatif hambatan yang mungkin dihadapi mahasiswa dalam mengaplikasikan konten modul dalam keseharian, konten materi lebih condong pada memberikan pemahaman dan belum pada pemberikan kemampuan, serta daftar pustaka masih didominasi oleh buku, akan jauh lebih baik jika dilengkapi dengan studi jurnal terkait.

Berdasarkan masukan, kritik dan saran yang diberikan oleh ahli materi keterampilan belajar, maka tindak lanjut yang dilakukan adalah melakukan revisi materi modul. Namun demikian, tidak semua masukan yang diberikan oleh ahli materi seluruhnya direalisasikan karena harus disesuaikan dengan karakteristik serta waktu yang diperlukan untuk memperbaiki serta estimasi waktu penggunaannya oleh mahasiswa. Beberapa tindak lanjut yang dilakukan adalah (a) menambahkan materi tentang "menumbuhkan passion" pada Unit 1 Merumuskan Tujuan, (b) menambahkan subbab tentang trouble shooting dalam Unit 2 Mengelola Waktu, dan (c) menambahkan sub bab tentang meningkatkan kemampuan untuk konsentrasi (memusatkan perhatian) pada Unit 3 Membaca Efektif.

2. Ahli Desain dan Media Pembelajaran

Dari hasil penyebaran kuesioner dan kegiatan wawancara, ahli materi modul dan desain pembelajaran menyatakan bahwa modul yang dikembangkan sudah baik, namun masih perlu perbaikan.

Berdasarkan masukan-masukan yang diberikan, peneliti melakukan perbaikan/revisi modul sebagai tindak lanjut dari masukan-masukan yang telah diberikan oleh ahli desain dan media pembelajaran (modul). Semua masukan tersebut dapat diterima oleh peneliti sebagai bahan untuk perbaikan modul.

3. Ahli Bahasa

Dari penyebaran kuesioner dan kegiatan wawancara, ahli bahasa menyatakan bahwa modul yang dikembangkan sudah baik. Beberapa masukan dari ahli bahasa adalah (a) masih terdapat kesalahan dalam penulisan; (b) jarak antar paragraf yang ada bullet and numbering nya terlalu rapat. Sebaiknya diatur spasinya agar tidak terkesan terlalu rapat; dan (c) gaya bahasa yang digunakan mudah dimengerti dan sesuai dengan responden

Berdasarkan masukan-masukan tersebut, peneliti melakukan perbaikan/revisi modul sebagai tindak lanjut dari masukan-masukan yang telah diberikan oleh ahli bahasa. Semua masukan tersebut dapat diterima oleh peneliti sebagai bahan untuk perbaikan modul.

\section{b. One to one evaluation}

Uji coba one to one dilaksanakan di Universitas Negeri Jakarta. Mahasiswa FIP UNJ yang dilibatkan dalam uji coba one to one berjumlah 6 orang, akan tetapi 1 orang mahasiswa berhalangan hadir, total yang hadir sebanyak 5 orang. Saat uji coba one to one mahasiswa diminta membaca isi modul, secara bertahap mulai dari unit 1. Selama proses membaca apabila mahasiswa mengalami kesulitan dalam memahami isi modul, maka mahasiswa diperkenankan bertanya dan memberi feedback untuk bagian modul yang perlu ditambah penjelasan atau bahasanya perlu disederhanakan sehingga lebih mudah dipahami. Penulis mencatat kesan dan masukan dari mahasiswa selama proses membaca modul per unit.

Secara keseluruhan mahasiswa responnya positif, antusias dan fokus dalam proses membaca modul serta merasakan manfaatnya bahwa pengetahuan yang diperoleh saat uji dapat segera dipraktikkan dalam studi di perguruan tinggi. Selain itu mahasiswa diminta mengisi kuesioner sebagai umpan balik, setelah selesai membaca modul mulai dari unit 1 sampai dengan unit 5 . Hasil pengisian kuesioner mahasiswa pada tahap one to one evaluation disajikan pada tabel 1.

Tabel 1. Hasil Kuesioner One to One Evaluation

\begin{tabular}{cccccc}
\hline \multicolumn{1}{c}{ Aspek } & Kurang & Cukup & Baik & $\begin{array}{c}\text { Sangat } \\
\text { Baik }\end{array}$ & n \\
\hline Penyajian Isi & 1 & 37 & 65 & 42 & 145 \\
Bahasa & 10 & 17 & 21 & 12 & 60 \\
Kegrafikan & 12 & 22 & 26 & 19 & 79 \\
\hline \multicolumn{1}{c}{$\mathbf{N}$} & 23 & 76 & 112 & 73 & 284 \\
\hline \multicolumn{1}{c}{$\%$} & 8 & 27 & 39 & 26 & 100 \\
\hline
\end{tabular}

Selain itu mahasiswa diminta memberikan kesan dan saran secara keseluruhan setelah membaca modul Keterampilan Belajar. Adapun deskripsi kesan dan saran mahasiswa sebagai berikut.

Pertama, "buku diperkaya dengan warna dan 
gambar, dan agar lebih menarik bagi anak-anak muda, Kalau bisa dibuat versi gaul agar anak muda semakin menarik dan ingin tahu dengan buku tersebut. Buku ini membuat saya jadi tahu belajar yang cocok untuk saya".

Kedua, "buku ini sangat membantu untuk mahasiswa baru seperti saya. Saya harap kekurangan seperti sulit untuk dipahami, panjang kalimat sebaiknya sedikit dikurangi. Banyak kata-kata agak kurang dipahami oleh saya, terlalu berbelit-belit untuk orang awam seperti saya".

Ketiga, "kalimat di dalam buku lebih dibuat simple, untuk penjelasan diperbanyak contoh yang dapat dimengerti oleh khalayak ramai".

Keempat, saran untuk modul ini harus lebih banyak variasi warna dan gambar agar tidak jenuh dan bosan. Materi jangan terlalu panjang, jadi bingung di akhir. Tapi modul ini tetap keren, akurat, dan lengkap sekali.

Kelima, materi pembahasan lebih diringkas, divariasikan dengan gambar. Soal latihan juga lebih bervariasi agar lebih menarik.

Setelah mempertimbangkan berbagai kesan dan saran mahasiswa dari hasil uji coba one to one, maka perbaikan yang dilakukan oleh penulis, antara lain sebagai berikut.

Pertama, revisi perbaikan pada Unit 1 Perumusan Tujuan, menambahkan contoh-contoh passion agar mahasiswa lebih mengenal passionnya masing-masing

Kedua, revisi perbaikan pada Unit 2 Pengelolaan Waktu, pada bagian latihan dan tes formatif 2 tabel Jadwal Mingguan diperbesar kolom kegiatan setiap harinya, sehingga mahasiswa lebih leluasa mengisi kegiatan harian.

Ketiga, revisi perbaikan pada Unit 3 Membaca Efektif, artikel Tes Formatif 2 tentang "Darimana Asal Manusia" lebih diringkas supaya tidak membosankan mahasiswa, paragraf 1 dan 2 dihapus. Kunci jawaban juga direvisi disesuaikan dengan jumlah dan isi paragraf.

Keempat, revisi perbaikan pada Unit 4 Mencatat Efektif, menambah ilustrasi mengenai mencatat efektif.

Keenam, revisi perbaikan untuk Unit 5 Mengingat Efektif, Metode mengingat yang sulit bila dipelajari secara mandiri dan kurang relevan dengan mahasiswa dihapus, seperti metode Sanjak, metode Kata Kunci, dan metode Imej-Teknik Penamaan. Pada latihan dan tes formatif 2 dalam unit 3 juga ditambahkan petunjuk pengerjaan latihan dan tes formatif agar lebih mudah dipahami mahasiswa.

\section{c. Small Group}

Uji coba small group melibatkan 10 mahasiswa.

Uji coba dilakukan selama 2 hari agar mahasiswa dapat lebih fokus mempelajari isi modul dan tidak lelah selama di perjalanan apabila tidak menginap. Saat uji coba small group, mahasiswa diminta membaca isi modul, secara bertahap mulai dari unit 1. Selama proses membaca apabila mahasiswa mengalami kesulitan dalam memahami isi modul, maka mahasiswa diperkenankan bertanya dan memberi feedback untuk bagian modul yang perlu ditambah penjelasan atau bahasanya perlu disederhanakan sehingga lebih mudah dipahami. Mahasiswa diminta mencatat kesan, kesulitan dan memberi masukan selama proses membaca modul per unit.

Secara keseluruhan kegiatan uji coba small group kondusif, respon mahasiswa positif, antusias dan fokus dalam proses membaca modul serta merasakan manfaatnya bahwa pengetahuan yang diperoleh saat uji coba small group dapat segera dipraktikkan dalam studi di perguruan tinggi. Selain itu mahasiswa diminta mengisi kuesioner sebagai umpan balik, setelah selesai membaca modul mulai dari unit 1 sampai dengan unit 5 . Hasil pengisian kuesioner mahasiswa pada tahap small group disajikan pada tabel 2.

Tabel 2. Hasil Kuesioner Small Group

\begin{tabular}{cccccc}
\hline \multicolumn{1}{c}{ Aspek } & Kurang & Cukup & Baik & $\begin{array}{c}\text { Sangat } \\
\text { Baik }\end{array}$ & n \\
\hline Penyajian Isi & 20 & 101 & 123 & 46 & 290 \\
Bahasa & 24 & 51 & 51 & 4 & 130 \\
Kegrafikan & 22 & 65 & 58 & 12 & 157 \\
\hline \multicolumn{1}{c}{$\mathbf{N}$} & 66 & 217 & 232 & 62 & 577 \\
\hline \multicolumn{1}{c}{$\%$} & 11 & 38 & 40 & 11 & 100 \\
\hline
\end{tabular}

Selain itu mahasiswa diminta memberikan saran/ masukan/ tanggapan secara keseluruhan setelah membaca modul Keterampilan Belajar. Adapun deskripsi saran/masukan/tanggapan mahasiswa sebagai berikut. Pertama, tampilan fisik sebaiknya dibuat lebih menarik lagi. Kedua, buku sudah menarik tambahkan contoh-contoh soal. Ketiga, secara keseluruhan modul sudah cukup baik, jika dilihat dari berbagai aspek. Namun, alangkah baiknya apabila konten modul tidak terlalu padat dan diperhatikan lagi mengenai EYD, penggunaan bahasa, banyaknya latihan/tugas, dan kepraktisan tentang ilustrasinya. Keempat, seharusnya menggunakan kertas yang tidak membuat cepat lelah. 
Selain itu, ada baiknya di evaluasi kembali tampilan bukunya. Kelima, untuk keseluruhan, modul ini sudah cukup bagus tetapi harus dibuat lebih menarik dengan warna yang banyak.

d. Field Trials

Uji coba field test melibatkan 20 orang mahasiswa. Saat field test, sebelumnya mahasiswa diminta untuk mengisi pre test terkait materi keterampilan belajar. Hal ini bertujuan untuk mengukur pengetahuan awal mahasiswa sebelum mempelajari isi modul. Selanjutnya mahasiswa diminta membaca isi modul, secara bertahap mulai dari unit 1.

Selama proses membaca apabila mahasiswa mengalami kesulitan dalam memahami isi modul, maka mahasiswa diperkenankan bertanya dan memberi feedback untuk bagian modul yang perlu ditambah penjelasan atau bahasanya perlu disederhanakan sehingga lebih mudah dipahami. Mahasiswa diminta mencatat kesan, kesulitan dan memberi masukan selama proses membaca modul per unit. Setelah selesai membaca dan mengerjakan evaluasi formatif modul, siswa diminta untuk mengisi post test terkait materi keterampilan belajar yang sudah dipelajari, hal ini bertujuan untuk mengukur perubahan peningkatan pengetahuan mahasiswa sebelum dan sesudah mempelajari dan mengerjakan evaluasi formatif di dalam modul.

Berdasarkan data yang diperoleh dari hasil rekapitulasi nilai hasil pre test dan post test mahasiswa ujicoba field test maka dapat disimpulkan sebagai berikut. Dari 20 mahasiswa yang mengikuti uji coba field test, setelah mengerjakan pre test rata-rata nilainya adalah 40,8, sedangkan setelah mengikuti post test rata-rata nilainya meningkat menjadi 55,4 dengan selisih peningkatan sebesar 14,6 poin. Sedangkan dari total 20 orang, ada 6 orang yang nilai rata-rata pre test 43,3 dan hasil post testnya meningkat menjadi 74 poin, Oleh karena itu, dapat disimpulkan bahwa sebagian besar hasil post test mahasiswa ada sedikit peningkatan nilai, sedangkan ada sebagian mahasiswa nilai post testnya meningkat signifikan.

Secara keseluruhan kegiatan uji coba field test berjalan kondusif, respon mahasiswa positif, antusias dan cukup fokus dalam proses mempelajari modul serta merasakan manfaatnya bahwa pengetahuan yang diperoleh saat uji coba field test dapat segera dipraktikkan dalam studi di perguruan tinggi. Selain itu mahasiswa diminta mengisi kuesioner sebagai umpan balik, setelah selesai membaca modul mulai dari unit 1 sampai dengan unit 5. Hasil pengisian kuesioner mahasiswa pada tahap field trials disajikan pada tabel 3.

Tabel 3. Hasil Kuesioner Field Test

\begin{tabular}{lccccc}
\hline \multicolumn{1}{c}{ Aspek } & Kurang & Cukup & Baik & $\begin{array}{c}\text { Sangat } \\
\text { Baik }\end{array}$ & n \\
\hline Penyajian Isi & 1 & 95 & 346 & 138 & 580 \\
Bahasa & 2 & 48 & 169 & 41 & 260 \\
Kegrafikan & 8 & 48 & 200 & 64 & 320 \\
\hline \multicolumn{1}{c}{$\mathbf{N}$} & 11 & 191 & 715 & 243 & 1160 \\
\hline \multicolumn{1}{c}{$\%$} & 1 & 16 & 62 & 21 & 100 \\
\hline
\end{tabular}

Selain itu berdasarkan hasil isian kuesioner umpan balik field test dapat dikelompokkan dan disimpulkan beberapa kesan dan saran dari mahasiswa. Kesan mahasiswa setelah mempelajari isi modul antara lain sebagai berikut. Pertama, uji coba sangat bagus berjalan baik. Kedua, modul ini bahasanya komunikatif, sederhana, mudah dimengerti, menginspirasi dan memotivasi. Ketiga, kertas yang digunakan untuk modul ini bagus. Keempat, secara keseluruhan modul ini sudah sangat baik, sangat menarik, mendorong pembaca ingin lebih tahu dan membantu untuk mempelajari. Modul ini sangat efektif dan efisien, mudah diingat materimaterinya. Kelima, modul ini isinya bagus sekali untuk mahasiswa baru, isi modul juga inspiratif. Keenam, buku ini sangat memotivasi untuk seseorang yang ingin menjadi mahasiswa yang baik. Sangat membantu kita untuk berpikir dan mencari lebih jauh bagaimana kita untuk merumuskan tujuan perkuliahan dengan baik

Dari kesan sebagian mahasiswa di atas dapat disimpulkan bahwa field test berjalan dengan baik, secara keseluruhan kualitas modul sudah sangat baik, sangat menarik, memotivasi dan membantu mahasiswa baru untuk mempelajari isi modul, dengan bahasa yang sederhana, komunikatif dan menginspirasi sehingga materi modul mudah diingat, efektif dan efisien. Adapun sebagian saran dari mahasiswa mengenai isi modul antara lain sebagai berikut.

1. Fisik Modul: bahan modul/kertas terlalu terang sehingga mata mudah lelah ketika terlalu lama membaca, penjilidannya masih kurang baik.

2. Desain Modul: Desain sampul kurang menarik dan kaku, sehingga terkesan terlalu tua untuk para mahasiswa baru. Bahan modul

3. Bahasa modul: (a) sebaiknya bahasa yang digunakan konsisten, memilih menggunakan 
bahasa baku atau tidak baku; (b) masih ada bahasa yang sulit dipahami sehingga perlu dibaca ulang ; perlu disederhanakan kata-kata yang sulit; (c) masih ada kesalahan ketik; (d) banyak tanda baca yang tidak sesuai ataupun hilang; dan (e) terdapat font size yang tidak konsisten

4. Ilustrasi / visual modul : visual dan gambarnya perlu ditambah lagi, diberi penekanan berupa warna yang berbeda pada pokok-pokok atau inti materi.

5. Tata letak: paragraf terlalu masuk ke dalam jadi membacanya mesti ditekuk modulnya.

6. Waktu mempelajari modul : waktunya sangatlah sedikit, yang membuat peserta tidak fokus dan banyak yang kelelahan karena kurangnya jam istirahat.

7. Tes Formatif : (a) petunjuk beberapa latihan soal perlu diperjelas, (b) untuk soal latihan sebaiknya diberi lebih banyak variasinya, (c) perlu beberapa revisi di bagian tes formatif yang kadang masih membuat bingung, dan (d) dari setiap tes yang diberikan perlu petunjuk yang lebih lanjut karena buku pegangan tersebut merupakan buku pegangan sendiri tanpa tutorial video

Selain menyebarkan kuesioner, pada tahap filed trials juga dilakukan pre-test dan post test untuk mengetahui peningkatan keterampilan belajar setelah mempelajari modul. Hasil uji coba tersebut disajikan pada tabel 4 .

Tabel 4. Hasil Uji Coba Pretest dan Postest

\begin{tabular}{cccc}
\hline \multirow{2}{*}{ Responden } & \multicolumn{3}{c}{ Nilai } \\
\cline { 2 - 4 } & Pre-test & Post-test & Peningkatan Nilai \\
\hline 1 & 36 & 56 & 20 \\
2 & 52 & 76 & 24 \\
3 & 52 & 56 & 4 \\
4 & 36 & 72 & 36 \\
5 & 36 & 76 & 40 \\
6 & 32 & 48 & 16 \\
7 & 48 & 48 & 0 \\
8 & 44 & 44 & 0 \\
9 & 48 & 44 & -4 \\
10 & 48 & 52 & 4 \\
11 & 48 & 76 & 28 \\
12 & 40 & 44 & 4 \\
13 & 44 & 48 & 4 \\
14 & 36 & 68 & 32 \\
15 & 36 & 44 & 8 \\
16 & 44 & 40 & -4 \\
17 & 32 & 48 & 16
\end{tabular}

\begin{tabular}{cccc}
\hline \multirow{2}{*}{ Responden } & \multicolumn{2}{c}{ Nilai } & Peningkatan Nilai \\
\cline { 2 - 3 } & Pre-test & Post-test & \\
\hline 18 & 20 & 44 & 24 \\
19 & 52 & 76 & 24 \\
20 & 32 & 48 & 16 \\
\hline Rata-Rata & 40.8 & 55.4 & 14.6 \\
\hline
\end{tabular}

\section{Pembahasan}

Berdasarkan hasil ujicoba yang dilakukan kepada ahli modul dan desain pembelajaran, ahli materi, serta ahli Bahasa menunjukkan bahwa modul yang dikembangkan sudah baik. Namun demikian, masih perlu dilakukan perbaikan-perbaikan sebelum diujicobakan kepada mahasiswa. Perbaikanperbaikan yang dilakukan berdasarkan atas saran dan masukan para ahli. Tidak semua masukan dan saran dapat diterima seperti masukan yang diberikan oleh ahli materi mengenai tambahan penjelasan mengenai metode peningkatan fokus. Hal ini dilakukan karena jika konten tersebut ditambahkan maka materi yang disajikan dalam modul akan terlalu luas. Oleh karena itu, tidak ada penambahan mengenai penjelasan tersebut.

Setelah dilakukan perbaikan atas saran dan masukan dari para ahli, maka modul diujicobakan kepada mahasiswa dengan tiga tahap: (a) one to one evaluation, (b) small group, dan (c) field trials. Dari ujicoba yang dilakukan menunjukkan bahwa, baik pada tahap one to one evaluation, small group, maupun field trials, Modul Keterampilan Belajar untuk Mahasiswa sudah baik.

Berbagai masukan yang diberikan oleh mahasiswa menjadi bahan pertimbangan untuk memperbaiki draf modul berikutnya. Namun tidak semua masukan mahasiswa diterima. Hal ini disebabkan karena masukan tersebut kurang tepat jika mengacu kepada teori. Sebagai contoh, penambahan warna pada aspek grafika modul agar terlihat menarik. Meskipun penambahan warna dapat menambah daya tarik, namun oleh karena yang menjadi sasaran pengguna adalah mahasiswa, yang dapat dikatakan sebagai orang dewasa, maka fungsi warna tersebut tidak terlalu fungsional dan tidak memberikan makna. Selain ini, penambahan warna juga dapat meningkatkan biaya produksi modul. Oleh karena itu, penambahan warna yang hanya bersifat dekoratif atau kurang fungsional tanpa memberikan makna, maka saran tersebut tidak ditinjaklanjuti.

Selain itu, hasil pretest dan posttest menunjukkan adanya peningkatan rata-rata meskipun hanya 
sedikit. Hasil post-test menunjukkan bahwa tidak ada mahasiswa yang mencapai nilai 80 . Hal ini disebabkan karena ketika ujicoba dilakukan, hampir semua mahasiswa tidak bisa konsentrasi dalam mempelajari modul. Tidak konsentrasinya mahasiswa dikarenakan mereka dikumpulkan dalam satu ruangan dengan temannya, sehingga kemungkinan besar mereka memanfaatkannya untuk membicarakan hal-hal di luar kepentingan modul keterampilan belajar selama ujicoba berlangsung.

Selain itu, waktu uji coba hanya dilaksanakan selama dua hari satu malam. Mahasiswa merasa waktu yang tersedia masih kurang. Sehingga dapat disimpulkan agar penggunaan modul keterampilan belajar tersebut membuahkan hasil yang optimal, maka diperlukan waktu yang tidak sedikit. Hal ini terlihat dari hasil ujicoba telah menunjukkan peningkatan rata-rata, apalagi jika modul tersebut digunakan dalam rentang waktu yang lebih lama, mahasiswa tentu akan lebih leluasa untuk mempelajarinya sehingga peningkatan ketrampilan belajar menjadi lebih optimal.

\section{PENUTUP}

\section{Kesimpulan}

Keterampilan belajar merupakan hal yang penting untuk dimiliki bagi setiap mahasiswa untuk menunjang perkuliahannya. Untuk membantu meningkatkan ketrampilan belajar, mahasiswa mahasiswa memerlupkan bahan belajar mandiri. Bahan belajar mandiri yang dimaksud adalaah Modul Ketrampulan Belajar Untuk Mahasiswa.

Modul Keterampilan Belajar Untuk Mahasiswa telah melewati tahapan-tahapan ujicoba. Dari ujicoba yang dilakukan menunjukkan bahwa, baik pada tahap expert review, one to one evaluation, small group, maupun field trials, Modul Keterampilan Belajar Untuk Mahasiswa sudah baik Berdasarkan hasil penelitian menunjukkan bahwa Modul Keterampilan Belajar Untuk Mahasiswa telah terbukti dapat meningkatkan keterampilan belajar mahasiswa.

\section{Saran}

Untuk menggunakan modul tersebut, beberapa hal yang perlu diperhatikan sebagai berikut. Pertama, untuk menggunakan modul tersebut, dibutuhkan rentang waktu yang tidak sedikit agar mahasiswa mampu mempelajari modul dengan leluasa. Kedua, oleh karena modul tersebut bersifat mandiri, maka pengguna modul harus sudah memiliki kemampuan belajar mandiri. Ketiga, kehadiran fasilitator merupakan hal pendukung dalam penggunaan modul tersebut untuk menunjang mahasiswa meningkatkan keterampilan belajarnya.

\section{DAFTAR PUSTAKA}

Belawati, T dkk. (2003). Pengembangan bahan ajar. Jakarta: Universitas Negeri Jakarta

Budiarjo, L. (2008). Keterampilan belajar: Belajar bagaimana belajar. Yogyakarta: Andi

Fry, R. (2008). How to study. Diterjemahkan oleh PT. Bhuana Ilmu Populer USA: Career Press

Kompasiana. (2011). Kualitas SDM Indonesia di dunia. Diakses dari situs http://ekonomi. kompasiana.com/bisnis/2011/03/14/kualitassdm-Indonesia -di-dunia/ pada tanggal 7 Maret 2012.

Kompasiana. (2011). Tantangan SDM Indonesia di era globalisasi. Diakses dari situs http://regional. kompasiana.com/2011/06/16/tantangan-sdmindonesia -di-era-globalisasi/ pada tanggal 7 Maret 2012.

Prawiradilaga, D.S. (2006). Penulisan modul untuk pelatihan peneliti. Jakarta: LIPI

Pusat Komputer UNJ, Rata-rata Indeks Prestasi Kumulatif Semester Ganjil 083 UNJ tahun Angkatan 2005-2006.

Seel, B.B., \& Richey, R C. (2004). Instructional technology: The definition and domains of the field (diterjemahkan oleh Dewi S. Prawiladilaga, Raphael Raharjo dan Yusufhadi Miarso. Jakarta: UNJ.

Sitepu, B.P. (2004). Penyusunan buku pelajaran. Jakarta: Verbum Publishing

Sitepu, B.P. (2008). Pengembangan sumber belajar. Jurnal Pendidikan Penabur - No.11/Tahun ke-7/ Desember 2008

Sudrajat, A. (2008). Sumber belajar untuk mengefektifkan pembelajaran siswa. Diakses dari situs http:// akhmadsudrajat.wordpress.com/2008/04/15/ sumber-belajar-untuk-mengefektifkanpembelajaran-siswa/ pada tanggal 16 April 2013.

Suparman, M.A. (2005). Desain pembelajaran. Jakarta: PAU-PPAI Universitas Terbuka

UNJ. (2009). Buku pedoman akademik UNJ 2009/2010. Jakarta: UNJ. 